\title{
PERLINDUNGAN HUKUM WARGA NEGARA TERHADAP TINDAKAN PEMERINTAH DALAM MEMBUAT KEPUTUSAN ADMINISTRASI NEGARA
}

\author{
Herman \\ Fakultas Ilmu Sosial \\ Universitas Negeri Makassar \\ E-mail : hermanhrm17@ymail.com
}

\begin{abstract}
ABSTRAK
Perkembangan tugas-tugas negara pasca memasuki abad ke 20 menuntut negara semakin aktif dalam pergaulan di dalam masyarakat. Era ini merupakan babakan perkembangan negara yang menuntut negara hukum modern semakin mempunyai banyak kewajiban-kewajiban. Negara tidak hanya dibebani kewajiban sebagai penjaga kemanan dan ketertiban di masyarakat, namun negara juga dibebani berbagai macam kewajiban dalam rangka pencapaian masyarakat sejahtera. Tindakan atau perbuatan pemerintah semakin beragam, baik dalam rangka menjalankan undang-undang, membuat undang-undang, perencanaan, membuat keputusan, termasuk kewenangan bebas. Keputusan administrasi negara merupakan salah satu tindakan pemerintah dalam rangka menjalankan undang-undang. Tindakan ini merupakan tindakan hukum pemerintah dalam menjalankan funsi publiknya. Memahami tindakan pemerintah dalam membuat keputusan administrasi negara merupakan hal penting untuk menjaga dan melindungi warga negara dari tindakan itu. Tindakan pemerintah melalui organ/pejabatnya ini terkait dengan akibat hukum yang ditimbulkannya terhadap warga negara.
\end{abstract}

Kata Kunci : keputusan administrasi negara, tindakan hukum pemerintah, dan perlindungan hukum warga negara.

\section{ABSTRACT}

Development tasks after entering the country 20th century demanding increasingly active in the association state in society. This era is the scene of the development of the country demanding more modern constitutional state has many obligations. State not only burdened with the obligation as security guards and order in the community, but the country also burdened with a wide range of obligations in order to achieve a prosperous society. The act or acts of government increasingly diverse, both in order to carry out the laws, enact laws, planning, making decisions, including free authority. The decision of state administration is one of the government's actions in order to carry out the law. This action is the government's legal action in the run function is public. Understanding the actions of the government in making decisions of state administration is essential to maintain and protect the citizens of the action. Government action through organ / officials is related to the legal consequences arising against citizens. 
Keywords: decision of the state administration, the government's legal action, and legal protection of citizens.

\section{Pendahuluan}

Dinamika masyarakat pada saat ini, apalagi ditunjang oleh teknologi dan dengan akses informasi yang cepat menuntut administrasi negara mampu mengikuti dinamika dari masyarakat itu. Administrasi negara selaku pemangku kewajiban dalam melaksanakan fungsi publiknya dituntut cepat tanggap terhadap permasalahan yang terjadi di dalam masyarakat dengan perubahannya yang cepat. Untuk mencapai kesejahteraan masyarakat, maka pemerintah mempunyai kedudukan sebagai penguasa dengan kewenangan membuat peraturan perundang-undangan, dan kedudukan sebagai pelayan masyarakat (public servant), bertugas mengurus, menyelenggarakan, dan melayani segala urusan dan kepentingan masyarakat (Sibuea, 2010).

Penguasa itu bisa pemerintah sebagai pemerintah (penguasa eksekutif) dan bisa juga pemerintah sebagai administrator (penguasa administrasi). Keduanya merupakan Penguasa Negara (overheid). Keputusan pemerintah selaku pemerintah tidak dirasakan efeknya oleh masyarakat secara langsung karena suatu keputusan pemerintah (regeringsbesluit) selalu bersifat umum, prinsipil, abstrak, dan impersonal. Keputusan ini tidak berkenaan dengan seorang individu tertentu dalam kasus tertentu. Efek langsung dari keputusan pemerintah

sebagai

administratorlah

yang

menimbulkan berbagai dampak karena keputusan administrasi (administratieve beschikking) selalu bersifat individual, kasual, konkret, dan khas (Atmosudirjo ,1994).

Pemerintah dalam hukum administrasi sebagai kesatuan, sebagai badan yang diberi kewenangan, dengan demikian berwenang untuk menetapkan tindakan, menurut hukum administrasi, dan olehnya itu mempengaruhi keadaan atau kondisi hukum orang lain, atau untuk menjalankan tindakan hukum (berdasarkan hukum perdata) arti badan pemerintah secara hukum.

Kepustakaan

Belanda mengartikan administrasi dengan istilah administratief recht dengan administrare, besturen. Besturen mempunyai pengertian fungsional-berarti fungsi pemerintahan, dan institusional atau strukturalkeseluruhan organ pemerintah. Bestuur merupakan lingkungan di luar pembentukan peraturan (regelgeving), dan peradilan (rechtspraak)( Hadjo, 2002).

Dalam menjalankan fungsi publik dari administrasi negara inilah akan menimbulkan berbagai macam dampak, terutama berkenaan dengan hakhak dari masyarakat, temasuk badan usaha di dalamnya yang dimiliki oleh masyarakat. Antara pemerintah selaku pemerintah dengan pemerintah selaku 
administraisi negara mengambil keputusan dengan wewenang yang sama, yakni "wewenang kenegaraan" atau wewenang publik. Namun Pemerintah selaku pemerintah mengambil keputusan pemerintahan, dan sebagai Administrator mengambil keputusan administratif. Selain itu keputusan pemerintah yang diambil merupakan pelaksanaan atau eksekutif (politieke daad)penegakan undang-undang dan wibawa negara, sedangkan keputusan administratif diambil sebagai keputusan penyelenggaraan atau realisasi (materiele daad) (Atmosudirjo).

Tindakan Pemerintah

Tugas-tugas publik yang ada dipundak administrasi negara ini tidak dapat dilepaskan dari landasan yang menjadi dasar administrasi negara dalam bertindak. Landasan dari tindakan yang diambil oleh administrasi negara tentunya berdasarkan pada ketentuan peraturan di dalam hukum administrasi negara (administratieve rechtsregels), sebagai dasar yang membenarkan tindakan itu secara hukum (juridische rechtsvaardiging), sesuai dengan konsep dari negara hukum. Peraturan hukum (rechtsregels) ini terkait dengan organisasi dari instansi administrasi negara (organische rechtsregels), dan mengenai fungsi-fungsi administrasi negara (functionele rechtsregels).

Atribusi, delegasi dan mandat merupakan sumber wewenang dalam negara hukum yang demokratis - salah satu asas negara hukum yang demokratis, bahwa setiap tindakan pemerintah harus berdasarkan atas hukum (asas legalitas, asas rechtmatigheid van bestuur). Setiap tindakan badan/pejabat tata usaha negara harus berdasarkan pada undangundang formal sebagai wujud dari pengakuan dan penghargaan terhadap kedaulatan rakyat. Atribusi dalam hal ini lebih penting artinya, apabila dikaitkan dengan adanya tindakan pemerintah yang meletakkan beban tertentu atau kewajiban tertentu kepada rakyatnya (Marbun , 2011).

Van Vollenhoven berpendapat, bahwa tindakan pemerintahan (Bestuurshandeling) merupakan merupakan suatu tindakan dalam rangka pemeliharaan kepentingan negara dan rakyat secara spontan dan tersendiri oleh penguasa tinggi dan rendahan. Komisi Van Poelje berdasarkan laporannya pada tahun 1972 mengartikan publiek rechtelijke handeling (tindakan dalam hukum publik) adalah tindakan hukum yang dilakukan oleh penguasa dalam menjalankan fungsi pemerintahan. Romeijn berpendapat bahwa tindakan pemerintahan adalah tiap-tiap tindakan atau perbuatan dari alat administrasi negara (bestuurs organ) yang mencakup juga perbuatan atau hal-hal yang berada di luar lapangan hukum tata pemerintahan, seperti keamanan, peradilan dan lain-lain dengan maksud menimbulkan akibat hukum dalam bidang hukum administrasi (Marbun, 2012).

Keterikatan dan keharusan untuk bertindak secara konsisten berdasarkan hukum yang berlaku 
bagi subjek hukum erat kaitannya dengan tanggung jawab atau tanggung gugat (responsibility or liability). Hukum merupakan instrumen dalam rangka kontrol terhadap setiap subjek hukum, termasuk pemerintah. Asas the rule of law menggariskan, bahwa pemerintah sekalipun, dalam kedudukan strukturalnya yang superior terhadap warga negara, harus bertindak berdasarkan hukum, seperti halnya warga negara biasa. Warga negara maupun kepada pemerintah, hukum harus berlaku sama sebagai panglima. Konsepsi ini dikenal sebagai asas supremasi hukum (supremacy of the law). Menurut Tamanaha, asas the rule of law berarti "Government officials and citizens be bound by and to act consistently with the law (Darumurti , 2012).

Asas legalitas adalah prinsip utama sebagai dasar penyelenggaraan pemerintahan dan kenegaraan yang berdasarkan hukum. Penyelenggaraan pemerintahan dan kenegaraan dalam negara hukum berdasarkan undang-undang, serta terdapatnya jaminan hak dasar rakyat, dan azas legalitas merupakan dasar legitimasi tindakan pemerintah dan jaminan perlindungan hak rakyat (Sudrajat , 2012).

Istilah perbuatan pemerintah merupakan terjemahan dari istilah bestuurhandeling (Belanda). Para ahli berbeda-beda dalam menerjemahkannya, ada yang menggunakan istilah perbuatan, dan ada pula yang menggunakan dengan istilah tindakan, bahkan ada yang menggunakan keduanya istilah "perbuatan atau tindakan". Perbuatan atau tindakan pemerintah merupakan tiap-tiap tindakan atau perbuatan dari suatu alat administrasi negara (bestuur organ), melingkupi juga perbuatan ataupun hal-hal yang berada di luar lapangan hukum administrasi negara, misalnya keamanan, peradilan dan yang lainnya. Tindakan ini dimaksudkan menimbulkan akibat hukum dalam bidang hukum administrasi, atau perbuatan pemerintah adalah perbuatan yang dilakukan oleh pejabat tata usaha negara dalam rangka melaksanakan urusan pemerintahan (Jufri , 2011).

\section{Tindakan Hukum Pemerintah}

E. Utrecht berpendapat, bahwa tindakan pemerintah itu dapat dilakukan dengan berbagai cara, yaitu ;

1. Yang bertindak adalah administrasi negara itu sendiri.

2. Yang bertindak adalah subyek hukum/badan hukum Iain yang tidak termasuk administrasi negara, dan dilakukan berdasarkan sesuatu hubungan istimewa, seperti badan hukum yang diberi monopoli.

3. Yang bertindak adalah subyek hukum lain yang tidak termasuk administrasi negara yang menjalankan pekerjaan berdasarkan suatu konsesi/izin dari pemerintah. Pekerjaan tersebut diserahkan oleh pemerintah kepada badan swasta untuk menyelenggarakan kepentingan umum.

4. Yang bertindak ialah subyek hukum lain yang tidak termasuk administrasi negara 
yang diberi subsidi oleh pemerintah, seperti yayasanyayasan pendidikan.

5. Yang bertindak adalah pemerintah bersama-sama dengan subyek hukum lain yang bukan administrasi negara di mana kedua belah pihak tergabung dalam kerjasama, seperti Bank Industri Niaga (di mana pemerintah bukan pemegang saham tetapi di dalam dewan direksinya ada wakil-wakil pemerintah).

6. Yang bertindak adalah yayasan yang didirikan/diawasi oleh pemerintah, seperti yayasan Supersemar, yayasan Veteran dan sebagainya.

7. Yang bertindak adalah koperasi yang didirikan/diawasi oleh pemerintah.

8. Yang bertindak adalah Perusahaan Negara, misalnya PLN.

Berdasarkan pendapat E. Utrecht di atas, maka tindakan pemerintah yang merupakan tindakan hukum untuk penyelenggaraan kepentingan umum, yaitu ;

1. Membebankan kewajiban pada organ-organ itu untuk menyelenggarakan kepentingan umum.

2. Mengeluarkan undangundang yang bersifat melarang atau yang ditujukan pada tiap-tiap warganegara untuk melakukan perbuatan (tingkah laku) yang perlu demi kepentingan umum.
3. Perintah-perintah atau ketetapan-ketetapan yang bersifat memberikan beban.

4. Memberikan subsidi-subsidi atau bantuan-bantuan kepada swasta.

5. Memberikan kedudukan hukum (rechtstatus) kepada seseoran sesuai dengan keinginannya, sehingga orang tersebut mempunyai hak dan kewajiban.

6. Melakukan pengawasan terhadap pekerjaan swasta.

7. Bekerjasama dengan perusahaan lain dalam bentuk-bentuk yang ditentukan untuk kepentingan umum.

8. Mengadakan perjanjian dengan warganegara berdasarkan hal-hal yang diatur dalam hukum.

Tindakan pemerintah (bestuurshandeling) adalah tindakan atau perbuatan yang dilakukan alat perlengkapan pemerintahan (bestuursorgaan) dalam rangka menjalankan fungsi pemerintahan (bestuursfunctie). Tindakan yang dilakukan oleh pemerintah ini ada yang merupakan Tindakan hukum (rechtshandeling) dan yang berupa tindakan nyata (feitelijkehandeling). Tindakan hukum (rechtshandeling) berdasarkan sifatnya merupakan tindakan yang dapat menimbulkan akibat hukum (menciptakan hak dan kewajiban).

Tindakan

hukum pemerintahan adalah tindakan yang diambil oleh badan atau pejabat tata usaha negara dalam melaksanakan urusan pemerintahan. Tindakan pemerintah memiliki unsur-unsur, yaitu (Syahrial, 2012): 
1. Perbuatan tersebut dilakukan oleh aparat pemerintah dalam kedudukannya sebagai penguasa maupun sebagai alat perlengkapan pemerintahan (bestuurs-organen) dengan prakarsa dan tanggung jawab sendiri;

2. Perbuatan tersebut dilaksanakan dalam rangka menjalankan fungsi pemerintahan;

3. Perbuatan tersebut dimaksudkan sebagai sarana untuk menimbulkan akibat hukum pada bidang hukum administrasi;

4. Perbuatan yang bersangkutan dilakukan dalam rangka pemeliharaan kepentingan negara dan rakyat.

Tindakan hukum pemerintah memiliki unsur-unsur, sebagai berikut (Sadjijono, 2001) :

1. tindakan tersebut dilakukan oleh aparatur pemerintah dalam kedudukannya sebagai penguasa maupun sebagai alat perlengkapan pemerintahan (bestuursorgaan);

2. tindakan dilaksanakan dalam rangka menjalankan fungsi pemerintahan

(bestuursfunctie);

3. tindakan dimaksudkan sebagai sarana untuk menimbulkan akibat hukum (rechtsgevolgen) di bidang hukum administrasi;

4. tindakan yang dilakukan dalam rangka pemeliharaan kepentingan umum;

5. tindakan dilakukan berdasarkan norma wewewenang pemerintah;
6. tindakan tersebut berorientasi pada tujuan tertentu berdasarkan hukum.

\section{Macam-macam Hukum Pemerintah} Tindakan

\begin{tabular}{cr}
\multicolumn{2}{c}{ Tindakan administrasi } \\
negara tidak selamanya
\end{tabular}
menimbulkan akibat hukum bagi masyarakat, oleh karena tindakan itu sifatnya non yuridis (tidak menciptakan akibat hukum), namun terdapat tindakan adminsitrasi negara yang menimbulkan akibat hukum (perbuatan hukum). Ada empat macam perbuatan hukum (rechtshandelingen) administrasi negara, yaitu(Atmosudirjo ) :

1. Penetapan (beschikking, administrative discretion);

2. Rencana (Plan);

3. Norma Jabaran (concreto normgeving);

4. Legislasi Semu (pseudowetgeving).

Tindakan hukum yang dilaksanakan oleh pemerintah dalam hukum administrasi negara, yaitu (Syahrial):

1. Tindakan hukum pemerintah/tata usaha negara berdasarkan hukum perdata atau hukum privat. Dua pendapat yang timbul tentang diperbolehkannya administrasi negara mengadakan hubungan hukum berdasarka hukum privat, yaitu:

a. Administrasi negara dalam menjalankan tugas pemerintahan tidak dapat menggunakan hukum privat, karena sifat hukum privat adalah hubungan hukum yang mengatur hubungan kehendak pada kedua belah pihak, serta bersifat perorangan. Hukum 
administrasi negara sebagai bagian dari hukum publik, serta merupakan hukum untuk bolehnya tindakan atas kehendak satu pihak.

b. Administrasi negara dapat menggunakan hukum privat. Akan tetapi, untuk menyelesaikan suatu soal khusus yang dalam lapangan administrasi negara telah tersedia peraturan-peraturan hukum publik.

2. Tindakan hukum tata usaha negara berdasarkan hukum publik ada 2 macam, yaitu:

a. Perbuatan Hukum Publik Bersegi Satu adalah perbuatan hukum publik yang merupakan kehendak satu pihak dari pemerintah, tidak melibatkan masyarakat.

b. Perbuatan Hukum Publik yang Bersegi Dua.

Tindakan hukum pemerintah ada yang berdasarkan hukum publik (Stroink), dan berdasarkan hukum privat. Tindakan berdasarkan hukum publik (publiekrechttelijke handeling) merupakan tindakan pemerintahan yang didasarkan pada hukum publik (bersifat hukum administratif dan memiliki akibat hukum administratif). Tindakan hukum publik ada yang bersifat sepihak (eenzijdig publiekrechtelijke handeling), dan yang bersifat dua pihak atau lebih (meerzijdik publiekrechtelijke handeling). Tindakan hukum publik yang bersifat sepihak (bersegi satu) yang dilakukan oleh alat-alat perlengkapan pemerintah ini disebut beschiking", yang dalam bahasa Indonesia disebut dengan istilah ketetapan atau keputusan", sedangkan tindakan hukum publik yang bersegi dua atau lebih, misalnya perjanjian kontrak kerja dengan pemerintah, atau "kortverband contract' (perjanjian kerja yang berlaku selama jangka pendek, yang dilakukan antara swasta dengan pemerintah) (Sadjijono).

Tindakan hukum publik yang bersegi satu maupun bersegi dua dapat dikatagorikan menjadi tiga bagian, yakni:

a. Tindakan membuat keputusan (beschikking);

Tindakan hukum publik yang bersifat sepihak (bersegi satu) dapat dibedakan menjadi tiga, yakni:

1) Sepihak - konkrit individual;

2) Sepihak - konkret - umum; dan

3) Lebih dari satu jabatan tata usaha negara - konkrit -umum.

b. Tindakan membuat peraturan (regeling), dan

Tindakan hukum pemerintah bidang hukum publik ini yang juga bersifat sepihak (bersegi satu) dan peraturan yang dikeluarkan bersifat umum-abstrak. Tindakan hukum dapat berbentuk peraturan pemerintah, peraturan presiden, peraturan menteri, peraturan gubernur dan lain-lain.

c. Tindakan

materiil (materiele daad).

Tindakan yang dilakukan dalam bentuk tindakan materiil dilakukan untuk kepentingan umum yang melibatkan dua pihak atau lebih, yakni pemerintah dan sipil (swasta) maupun pihak-pihak lain. Tindakan hukum publik ini, misalnya membuat perjanjian kerja, membuat memorandum of 
understanding (MOU), vortband contract, dan sebagainya.

Tindakan pemerintah yang berbentuk hukum privat merupakan tindakan pemerintah dalam kedudukannya bukan sebagai pemerintah. Tindakan ini sebagai wakil dari badan hukum (lichaam) dan bukan tugas untuk kepentingaan umum, sehingga tindakannya didasarkan pada ketentuan hukum privat (keperdataan). Apabila pemerintah bertindak dalam kualitasnya sebagai pemerintah, maka hukum publiklah yang berlaku dan apabila bertindak tidak dalam kualitasnya sebagai pemerintah, maka hukum privatlah yang berlaku (Jeddawi, 2012).

\section{Keputusan Administrasi Negara}

Keputusan administrasi negara pertama kali diperkenalkan oleh Otto Meyer dengan istilah verwaltungsakt. Di Belanda dikenal dengan nama beschikking oleh van Vollenhoven dan C. W. van der Port oleh beberapa penulis seperti AM. Donner, H.D. van Wijk/Willem Konijnenbelt, dan yang lainnya dianggap sebagai "de vader van het moderne beschikkingsbegrip", (bapak dari konsep beschikking yang modern). Di indonesia sendiri, istilah beschikking ini pertama kali diperkenalkan oleh WF. Prins (Ridwan, 2011).

$$
\text { Beberapa defenisi }
$$

keputusan administrasi negara dari para ahli, yaitu :

a. Van der Wel: Suatu pernyataan kehendak dari alat pemerintahan. b. W.F. Prins : Perbuatan hukum sepihak dalam lapangan pemerintahan yang dilakukan oleh penguasa, berdasarkan wewenang istimewa (diberikan oleh peraturan perundangundangan).

c. Van der Pot: perbuatan hukum dari alat-alat pemerintahan (bestuurs organ), yang merupakan pernyataa kehendaknya dalam suatu peristiwa khusus yang dilakukan dengan maksud mengadakan perubahan dalam hubungan hukum.

d. A. M. Donner: Perbuatan pemerintah yang dilakukan oleh jabatan pemerintah yang dalam hal tertentu dilakukan secara sepihak, dan dengan sengaja untuk menegakkan suatu hubungan hukum atau suatu kehendak yang telah ada atau yang telah menimbulkan suatu hubungan hukum, atau suatu keadaan hukum yang baru atau menolaknya (Anggriani, 2011).

e. H.J. Romeijn: Keputusan adalah suatu pernyataan kehendak yang disebabkan oleh surat permohonan yang diajukan, atau setidak-tidaknya keinginan atau keperluan yang dinyatakan (Beschikking; een wilsverklaring naar aanleiding van een ingediend verzoekschrift, of althans een gebleken wensch ofbehoefte).

f. C.J.N. Versteden: mendefinisi keputusan sebagai suatu tindakan hukum publik sepihak dari organ pemerintahan yang ditujukan pada peristiwa konkret (Eenvoudig geworden een definitie van het begrip beschikking te geven: Een eenzijdige publiekrechtelijke rechtshandeling 
van een bestuursorgaan gericht op een concreet geval).

g. J.B.M. ten Berge: Beschikking adalah keputusan hukum publik yang bersifat konkret dan individual: keputusan Itu berasal dari organ pemerintahan, yang didasarkan pada kewenangan publik...Dibuat untuk satu atau lebih individu atau berkenaan dengan satu atau lebih perkara atau keadaan. Keputusan itu memberikan suatu kewajiban pada seseorang atau organisasi, memberikan kewenangan atau hak pada mereka (Een beschikking is een individuele of concrete publiekrechtelijke rechts-beslissing: een beslissing van een bestuursorgaan, gebaseerd op een publiek-rechtelijke

bevoegheid...Geschapen voor een of meer individuen of met betrekking tot een of meer concrete zaken of situaties. Die beslissing verplicht mensen of organisaties tot iets, geeft ze bevoegdheden of geeft ze aanspraken).

h. R.J.H.M. Huisman: Secara umum, beschikking diartikan; keputusan yang berasal dari organ pemerintahan yang ditujukan untuk menimbulkan akibat hukum (Onder 'beschikking' kan in zijn algemeenheid worden verstaan: een besluit afkomstig van ten bestuursorgaan, dat gericht is op rechtsgevolg).

i. Sjachran

Basah:

Beschikking adalah keputusan tertulis dari administrasi negara yang mempunyai akibat hukum

j. E. Utrecht: Beschikking adalah perbuatan hukum publik bersegi satu (yang dilakukan oleh alat-alat pemerintahan berdasarkan suatu kekuasaan istimewa).

\begin{tabular}{lrr}
\multicolumn{2}{c}{ k. Soehino: } & keputusan \\
administrasi & negara & adalah \\
perbuatan & hukum & alat-alat
\end{tabular}
perlengkapan administrasi negara yang dilakukan berdasarkan wewenang yang diberikan kepadanya oleh aturan hukum inabstrakto dan unpersonal, berupa pembentukan aturan hukum inkonkrito mengenai suatu hal yang konkrit, dan terhadap subyek hukum yang konkrit (Soehino, 2000).

I. Paulus Effendi Lotulung: keputusan administrasi negara adalah produk yang diterbitkan oleh pejabat tata usaha negara (atau jabatan tata usaha negara) berdasarkan wewenang yang ada padanya (attributie) atau diberikan padanya dalam bidang urusan pemerintah (delegate) (Lotulung, 2013).

Keputusan Administrasi negara merupakan pengertian yang umum dan abstrak, dan dalam realisasinya mempunyai bentuk yang berbeda-beda, akan tetapi semua keputusan dari administrasi negara ini memiliki ciri dan sifat yang sama. Memahami keputusan administrasi negara ini penting, karena keputusan ini mempunyai konsekuensi dalam hukum positif yang mengakibatkan suatu akibat hukum. Sehingga dalam pengujiannya (toetsingsgronden), apabila terjadi permasalahan dapat diselesaikan secara baik dan benar berdasarkan hukum. keputusan yang dibuat berdasarkan pada suatu undang-undang yang jelas dan tegas disebut dengan keputusan terikat (gebonden beschikking) diuji oleh hakim berdasarkan peraturan perundang-undangan, dan suatu keputusan yang tidak secara tegas 
(sifatnya tersirat) disebut keputusan bebas (vrije beschikking) diuji oleh hakim berdasarkan pada asas-asas umum pemerintahan yang baik (Ridwan, 2001).

Sasaran keputusan ini
terdapat dua kemungkinan, yaitu ditujukan ke dalam (naar binnen gericht), adalah keputusan berlaku ke dalam lingkungan administrasi sendiri, dan ditujukan ke luar (naar buiten gericht), yang berlaku bagi warga negara atau badan hukum perdata.

Berdasarkan pembagiannya, maka terdapat dua jenis keputusan, yaitu keputusan intern (interne beschikking) dan keputusan ekstern (externe beschikking).

E. Utrecht berpendapat, bahwa terdapat berbagai macam keputusan, pertama, keputusan positif (menimbulkan hak dan kewajiban) dan negatif (tidak menimbulkan perubahan dalam keadaan hukum yang telah ada, kedua, keputusan deklaratur (menyatakan bahwa hukumannya demikian, rechtsvastellende beschikking) dan konstitutif (keputusan membuat hukum, rechtsheppend), ketiga, keputusan kilat dan keputusan yang tetap (blijvende), dan keempat, keputusan yang merupakan dispensasi, izin (vergunning), licentie, dan konsesi (Triwulan, 2011).

Berdasarkan sifatnya keputusan pemerintah dibedakan menjadi, pertama, keputusan pemerintah dalam arti eksekutif merupakan keputusan yang bersifat umum, prinsipil, abstrak dan impersonal-tidak berkenaan dengan seorang individu, dan tidak dalam suatu kasus tertentu (bentuknya adalah peraturan), merupakan keputusan pelaksana/eksekutif (politieke daad) dalam rangka penegakan undang-undang dan wibawa negara, kedua, keputusan pemerintah sebagai administrasi negara adalah keputusan yang sifatnya individual, kasuistis, konkrit atau nyata (bentuknya adalah keputusan, beschikking), merupakan keputusan penyelenggaraan/realisaasi

(materiale daad) (Anggriani ). Produk hukum dari badan/pejabat administrasi pemerintah yang berupa dokumen-dokumen yang mengandung materi penetapan yang bersifat konkret, individual, dan final dalam hukum administrasi disebut dengan keputusan (beschikking) (Syahrial).

Syarat material keputusan adalah: 1. Dibuat oleh organ pemerintah berwenang.

2. Tidak boleh memuat kekurangan atau cacat hukum.

3. Tidak boleh bertentangan dengan peraturan dasarnya.

Syarat formal keputusan adalah:

1. Dibuat berdasarkan prosedur yang ditentukan dalam peraturan dasarnya.

2. Diberi bentuk yang sudah ditentukan

3. Penentuan waktu berlaku.

4. Pengumuman (bekendmaking) atau pemberitahuan kepada yang terkena keputusan.

5. Tandatangan (ondertekening) pejabat yang berwenang. Antara keputusan administrasi negara dengan peraturan terdapat perbedaan, keputusan dibuat dalam rangka menyelesaikan hal konkrit, bersifat kasuistik, yang ditujukan kepada orang/individu tertentu. Peraturan dibuat untuk hal-hal 
yang bersifat abstrak yang belum diketahui sebelumnya, bersifat umum, dan yang mungkin akan terjadi di kemudian hari (Kusdarini, 2011).

Kesukaran membedakan antara keputusan dengan peraturan, ketika peraturan itu bersifat einmalig-suatu peraturan yang dibuat untuk menyelesaikan suatu perkara konkret dan setelah penyelesaian itu terlaksana kemudian peraturan itu berhenti dengan sendirinya tanpa dicabut, misalnya peraturan sebuah universitas yang mengatur tata cara pemilihan rektor antar waktu dikarenakan rektor yang terdahulu berhalangan tetap atau meninggal dunia.

\section{Simpulan}

Keputusan yang sah menurut hukum adalah keputusan yang memenuhi syarat formal dan syarat material. Hal ini didasarkan pada prinsip praduga rechtmatig,

\section{Daftar Pustaka}

Darda Syahrial, Hukum Administrasi Negara dan Pengadilan Tata Usaha Negara, Yogyakarta, Pustaka Yustisia, 2012.

Eny Kusdarini, Dasar-dasar Hukum Administrasi Negara dan Asasasas Umum Pemerintahan yang Baik, Yogyakarta, UNY Press, 2011.

F.A.M. Stroink, Pemahaman tentang Dekonsentrasi, Bandung, PT. Refika Aditama, 2006, terjemahan oleh Ateng Syafrudin. yaitu het vermoeden van rechtmatigheid atau presumtio justea causa (Setiap keputusan yang dikeluarkan oleh pemerintah atau administrasi negara itu dianggap sah menurut hukum). Prinsip ini berarti, bahwa setiap keputusan tidak untuk dicabut kembali, kecuali ada pembatalan (vernietiging) (Soetomo, 1981) dari pengadilan yang erat kaitannya dengan prinsip kepastian hukum (rechtszekerheidbeginsel).

Perubahan atau pencabutan suatu keputusan berlaku prinsip contrarius actus similiter fit (prosedur dan ketentuan perubahan atau pencabutan keputusan berlaku sama dengan prosedur dan ketentuan pembuatan), yang terkait dengan prinsip kewenangan (bevoegdheidsbeginsel) (Ridwan). Sifat norma hukum keputusan administrasi negara adalah individual dan konkrit, dan dalam rangakaian norma hukum merupakan norma penutup.

Hotma P. Sibuea, Asas Negara Hukum, Peraturan Kebijakan, dan Asas-asas Umum Pemerintahan yang Baik, Jakarta, Erlangga, 2010.

Jum Anggriani, Hukum Administrasi Negara, Yogyakarta, Graha Ilmu, 2012.

Juniarso Ridwan, dan Achmad Sodik Sudrajat, Hukum Administrasi Negara dan Kebijakan Pelayanan Publik, Bandung, Penerbit Nuansa, 2012. 
Khrisna D. Darumurti, Kekuasaan

Diskresi Pemerintah, Bandung, PT. Citra Aditya Bakti, 2012.

Muh. Jufri Dewa, Hukum Administrasi Negara, Kendari, Unhalu Press, 2011.

Murtir Jeddawi, Hukum Administrasi Negara, Yogyakarta, Total Media, 2012.

Paulus Effendi Lotulung, Hukum Tata Usaha Negara dan Kekuasaan, Jakarta, Salemba Humanika, 2013.

Philipus M. Hadjon, dkk, Pengantar Hukum Administrasi Indonesia, Yogyakarta, Gadjah Mada University Press, 2002.

Ridwan HR, Hukum Administrasi Negara; Edisi Revisi, Jakarta, PT. RajaGrafindo Persada, 2011.

Ridwan, Tiga Dimensi Hukum Administrasi dan Peradilan Administrasi, Yogyakarta, FH UII Press, 2009.

S. Prajudi Atmosudirjo, Hukum Administrasi Negara, Edisi Revisi; Seri Pustaka Ilmu Administrasi Negara VII, Jakarta, Ghalia Indonesia, 1994.

S.F. Marbun, Hukum Administrasi Negara I, Yogyakarta, FH UII Press, 2012.

S.F. Marbun, Peradilan Administrasi Negara dan Upaya Administratif di Indonesia, Yogyakarta, FH UII Press, 2011.

Sadjijono, Bab-bab Pokok Hukum Administrasi Negara, Yogyakarta, LaksBang Pressindo, 2001.

Soehino, Asas-asas Hukum Tata Usaha Negara, Yogyakarta, Liberty, 2000.
Soetomo, Pengantar Hukum Tata Pemerintahan, Malang, Lembaga Penerbitan Universitas Brawijaya, 1981.

Titik Triwulan dan Ismu Gunadi Widodo, Hukum Tata Usaha Negara dan Hukum Acara Peradilan Tata Usaha Negara Indonesia, Jakarta, Kencana, 2011. 